\title{
Effects of pre-treatment of Curauá fibers on compatibility with portland cements
}

Géssica Katalyne Bilcati ${ }^{1}$, Adalberto Matoski ${ }^{2}$, Rosilani Trianoski ${ }^{3}$, Elaine Cristina Lengowski ${ }^{4}$

\author{
${ }^{1}$ Departamento de Engenharia Civil. UTFPR, Av. Professora Laura Pacheco Bastos, 800/ Industrial, Guarapuava, PR, Brasil. \\ ${ }^{2}$ Departamento de Engenharia Civil. UTFPR, Rua Deputado Heitor Alencar Furtado, 5000/Ecoville, Curitiba, PR, Brasil. \\ ${ }^{3}$ Departamento de Engenharia e Tecnologia Florestal. UFPR, Av. Prefeito Lothário Meissner, 632/Jardim Botânico,Curitiba, \\ PR, Brasil. \\ ${ }^{4}$ Departamento de Engenharia Florestal. UnC, Rua Roberto Ehlke, 86, Centro, Canoinhas, SC, Brasil. \\ email:gessicak@utfpr.edu.br; adalberto@utfpr.edu.br; rosillani@gmail.com; elainelengowski@gmail.com
}

\begin{abstract}
There has been ever growing interest in the construction industry in using lighter, eco-friendly and sustainable materials, while maintainingthe desirable mechanical properties. The objective of the present work was to evaluate the effects of pre-treatments on chemical compatibility between Curauá fiber (Ananas erectifolius) and Portland cement. In the inhibition test, cement hydration temperature evolution wasmeasured in the absence and presence of untreated and treated Curauá fibers (cold water, hot water and $\mathrm{NaOH}$ ). The chemical characterization of untreated Curauá fibers was done by determining the content of extractives, lignin, holocellulose and ashes. Thee Segal's method was used for determinate the crystallinity index on untreated and treated fibers. The inhibition test graded the untreated fiber as high inhibition, showing the need to provide it a treatment. Treatments done on Curauá fibers removed some amorphous components of the fibers affected positively the compatibility between cement and fiber, and reducing the inhibition.
\end{abstract}

Keywords: Inhibition; chemical components; crystallinity; Ananas erectifolius.

\section{INTRODUCTION}

Cement composites reinforced with lignocellulosic materials are well-accepted products and largely used in construction. They add value to materials that have low acceptance such as sawmill residues or other wood processing wastes, becoming an alternative for application in construction, homes and buildings, reducing construction times while maintaining good performance, especially in developing countries, which have invested heavily in the technology $[1,2,3,4]$. The current global production of this material is estimated at approximately 30 million tons per year, mainly in Asian countries [4].

The physical and mechanical properties of cement-fiber panels, in addition to the facility of being sawn, glued, and nailed, are indicators of these composites applications. These characteristics allow them to be painted, rough casted, and coated with other types of materials. The versatility of the composite allows manufacturers to add value to the product by delivering it in sanded, painted, or coated forms. With this versatility, the composites can be used directly with finishing material. Although, the properties of these kinds of composites are greatly affected by: the species of lignocellulosic material, the binder type, additives, particle geometry, the lignocellulosic: cement ratio and others factors $[1,2,3]$.

Curauá (Ananas erectifolius) is a plant identified as being related to the pineapple (Ananas comosus), belonging to the genus of bromeliads. Genuinely Brazilian and originally found in the Amazon region, its lignocellulosic fibers have a large potential for use with excellent mechanical behavior, especially for use in civil construction $[5,6]$. 
The characteristics of the Curauá fiber has attracted attention due to their high strength capacity even with reduced thickness, the ability to withstand high stress, and also for being able to replace glass fiber, a key element used for the reinforcement of composites [7].

The chemical composition of the lignocellulosic materials (cellulose, tannins, hemicelluloses, lignin, ashes) depends on the type of soil where a plantgrowing, time of exposure to the climate during harvest, the form and duration of storage after harvest [8]. The chemical composition [9, 10,11] and other properties such as the crystallinity index and the chemical compatibility have a direct effect on the products made with lignocellulosic material[12,13], especially when these materials were used in the construction in the form of cement composites[1,2,3].

The chemical composition affects the reactivity, interfering in the chemical compatibility affecting the curing $[14,15]$ andmechanical strength of the cement panels $[12,13,16,17,18]$. Also, the crystalline and amorphous states of cellulose fibers affect their mechanical properties. The higher crystalline index results in the higher the density, rigidity, dimensional stability and chemical resistance properties [19].

Chemical incompatibility between the lignocellulosic fiber and cement is one of the major obstacles for a commercial scale production of composites based on mineral agglomerates [20]. The phenolic compounds, acids, soluble sugars, resins and extractives are responsible for this incompatibility when in contact with the alkaline medium created by cement. They solubilize and react with cement, preventing its crystallization and hardening $[21,22]$. The incompatibility index is show in the Table 1.

Table 1: Classification of lignocellulosic materials according to the inhibition index [10].

\begin{tabular}{l|l}
\hline Inhibition index & Classification \\
\hline $1 \leq 10$ & Low inhibition \\
\hline $10<\mathrm{I} \leq 50$ & Moderate inhibition \\
\hline $50<1 \leq 100$ & High inhibition \\
\hline $\mathrm{I}>100$ & Extreme inhibition \\
\hline
\end{tabular}

Some lignocellulosic fibers require treatment for modificated the chemical composition and then make them compatible with Portland cements, and the manufacturing of cement-fiber composites. Although there are many kinds of fibers, the use for made cement composites is limited to use a few species due to its chemical composition [15]. Some lignocellulosic materials can inhibit the crystals formation, essential elements for the development of strong links between matrix and reinforcement; therefore, vegetable fibers must be studied in order to determine the best way to treat them before using them [22,23].

Some treatments performed on the lignocellulosic fibers prior to the production of the compounds show significant improvements in the inhibitory properties, among them the extraction with cold water [24], with hot [25] aqueous solution of sodium hydroxide $(\mathrm{NaOH}) 1 \%$ [15].

Over time, vegetable fibers suffer with the alkaline attack of Portland cement, and the calcium hydroxide crystals resulting from cement hydration penetrate the fibers mineralizing and weakening them, also causing loss of adherence to the matrix [26]. This result decreased strength resistance of the composites, requiring alternatives to protect the fibers, either by modifying the matrix or by modifying the fibers [27].

In this context, considering the availability, characteristics and the importance to use of Curauá fiber to development new products, the aim of this work was to evaluate the effects of pre-treatments on chemical compatibility between Curauá fiber (Ananaser ectifolius) and Portland cement. 


\section{MATERIAL AND METHODS}

Curauá fibers (Ananas erectifolius) were obtained from the Center for the Support to Community Projects (CEAPAC) located in the Santarém, city at Pará state. The fibers were cut in 4-cm long pieces by PematecTriangel company also located in Santarém, after that, thenpassed through a knife mill to be disaggregated.

The chemical analyses of the fiber were performed in duplicate, following TAPPI's standards and procedures for determination of lignin [28] and ash [29] contents. Cold- and hot-water-soluble extractives [30], $1 \% \mathrm{NaOH}$-soluble extractives [31] and total extractives [32] were determinated according to the NBR standards; Holocellulose (Hol \%) was calculated by Equation 1 [33]:

$\operatorname{Hol}(\%)=100-(E T+L t)(1)$

Where: $\mathrm{Hol}(\%)=$ holocellulose content in percentual; $\mathrm{ET}=$ total extractives content; $\mathrm{Lt}=$ lignin content.

The fibers were submitted to pre-treatments, as shown in Table 2, following by washing under running water and drying in the open air. The same pre-treatments was used with tropical hardwoods fibers $[15,24]$ and lodge pole pine and western larch fiber [25] for production of cements composites. The binder used was CPV ARI Portland cement. Subsequently, assays were performed to determine the crystallinity index and inhibition.

Table 2: Experimental design.

\begin{tabular}{l|l}
\multicolumn{2}{c}{ Fibers treatments } \\
\hline Cold water & Immersion in water at room temperature for $24 \mathrm{~h}$ \\
\hline $\mathrm{Hot}$ water & Immersion in water at a temperature of $60^{\circ} \mathrm{C}$ for $6 \mathrm{~h}$ \\
\hline $\mathrm{NaOH}$ & Immersion in $\mathrm{NaOH}$ solution $(1 \%)$ for $2 \mathrm{~h}$ \\
\hline
\end{tabular}

Determination of the cellulose crystallinity index was performed at the Laboratory of X-Rays Optics and Instrumentation at Federal University of Paraná, the equipment used was an X-ray diffractometer (XRD - 7000 of Shimadzu). The configuration adopted for analysis was a monochromator provided with slots $(1 ; 1 ; 0.3)$, operating at $40 \mathrm{kV}$ with $20 \mathrm{~mA}$ currentand the speed adopted was $0.02^{\circ} . \mathrm{s}-1$ using $\mathrm{Cu}-\mathrm{K} \alpha$ radiation with wavelength of $0.5418 \mathrm{~nm}$.

The crystallinity index was obtained following the Segal et al., [34]'s method, the Origin Pro 8.5 software was used for data smoothing treatment by Fourier Transform with $15 \%$ cutoff points to obtain crystalline and amorphous peak intensity.

The inhibition assay for determination of the evolution of the cement hydration temperature in absence and presence of treated and non-treated fibers was conducted according to the methodology established by Hofstrand et al., [22]. The assays were conducted in quadruplicate, using the A202 data logger (Warme). In plastic bags were placed $200 \mathrm{~g}$ of cement, $1 \mathrm{~g}$ of dried Curauá fiber and $90 \mathrm{ml}$ of distilled water. Next, the "K" type thermocouple (device to measure temperature) with silicone protection, model KMP AFD 1P x 24 AWG, was introduced into the mixture. Each plastic bag containing the mixture was placed in a thermal container. The thermocouple was connected to a signal receiver and data were read and converted into temperature values by a computer program (Lynx). Readings were collected at intervals of 10 seconds during 24 hours.

To determine how much of the lignocellulosic material inhibits the cement exothermal reactions, inhibition of cement-fiber composites was measured according to Hofstrand et al.,[22] calculated as shown in Equation 2:

$I(\%)=\left[\frac{(\text { Tcim-Tm })}{\text { Tcim }} x \frac{(H m-H c i m)}{\text { Hcim }} x \frac{(\text { Scim-Sm })}{\text { Scim }}\right] \times 100$ 
Where: $\mathrm{I}=$ cement curing hydration rate $(\%) ; \mathrm{TCIM}=$ maximum temperature of cement/water mixture $\left({ }^{\circ} \mathrm{C}\right) ; \mathrm{TM}=$ maximum temperature of wood/cement/water mixture $\left({ }^{\circ} \mathrm{C}\right) ; \mathrm{HCIM}=$ time to reach maximum cement hydration temperature of cement/water (h); $\mathrm{HM}=$ time to reach maximum cement hydration temperature of the wood/cement/water $(\mathrm{h}) ; \mathrm{SCIM}=$ maximum temperature increase of the cement/water mixture curve $\left({ }^{\circ} \mathrm{C} / \mathrm{h}\right) ; \mathrm{SM}=$ maximum temperature increase of the wood/cement/water mixture curve $\left({ }^{\circ} \mathrm{C} / \mathrm{h}\right)$.

\section{RESULTS AND DISCUSSION}

\subsection{Chemical composition of the fibers}

The results from the chemical analyses are shown in Table 3:

Table 3: Chemical characterization of Curauá fiber.

\begin{tabular}{l|l}
\hline Lignin content (\%) & 5,10 \\
\hline Ash content (\%) & 0,82 \\
\hline Hot water extractives (\%) & 4,02 \\
\hline Cold water extractives (\%) & 3,65 \\
\hline $1 \%$ NaOH extractives (\%) & 15,26 \\
\hline Total extractives (\%) & 7,07 \\
\hline Holocellulose content (\%) & 87,07 \\
\hline
\end{tabular}

The results of chemical characterization (Table 3) are similar to findings by Mohanty, et al., [35] and Trindade et al., [36] and Castro et al., [37] to the same species. This raw material has a higher proportion of extractives and holocellulose (carbohydrate content), and lower content of lignin than others fiber species Silva and Aquino [38].The high holocellulose content and low lignin content of Curauá fiber makes the material with a high tensile strength. Among the natural fibers, the Curauá fiber is the one that presents mechanical properties closer to the glass fiber due to its chemical composition and high crystallinity [38, 40].

The percentage values of the chemical composition found in the work were holocellulose 87,07\%, lignin of $5,10 \%$, ash $0,82 \%$, total extractives of $7,07 \%$ and a solubility in $\mathrm{NaOH} 1 \%$ of $15,26 \%$. These values are in line with Silva and Aquino [38] for the same species, they found for the lignin content 7,5-11,1\%, cellulose content $70,7-73,6 \%$, the hemicellulose content $9,9 \%$.

The mean values of lignin content in Curauá fiber were lower when compared to the coconut fiber, 31$45 \%[39]$,juta fiber, $15 \%[12,35,41]$ and sisal fiber, $9,5 \%[12,35,39]$.

Curauá fiber has a higther value of holocellulose than coconut fiber, $65,83 \%[39]$, juta fiber, $66,25 \%[12$, $35,41]$ and sisal fiber, $27,5 \%[12,35,39]$.

The high content of holocellulose and low lignin content that the Curauá fiber presented makes the material with a high tensile strength. Among the natural fibers (Table 4), the Curauá fiber is the one that presents mechanical properties closer to the glass fiber due to its chemical composition and high crystallinity [12, 35,41, $38,40,42,43,44,45,46,47,48,49]$.

The content of soluble extractives in the treatment with hot water was higher than in the treatment with cold water, and the hot water treatment was more effective in removing extractives present in the fiber due to the action of temperature, which may have an influence on the wood fiber properties, changing the extractives behavior [42]. The solubility on sodium hydroxide was $15,26 \%$ higher when compared to the total extractives content because alkaline solutions promotes the partial removal of amorphous constituents such as hemicellulose, lignin and soluble oils [39,50,51]. 
The total extratives content of Curauá fiber was 7,07\%, and this value is considered relatively high when compared with other lignocellulosic materials.by comparing with coconut fibers, Ferrazet al.,[52] obtained 4,86\% and Leão et al., [42] 8,30\% as mean value which may possibly indicate that the coconut fibers exert less inhibition on cement curing and hardening. Regarding wood, the Pinusspecies more commercially used, Pinustaeda, also has mean values lower than the Curauá fiber, for which Andrade et al., [33] obtained mean content values of $3,03 \%$ and $2,15 \%$, respectively. When comparing with the Eucalyptus species, particularly Eucalyptus grandis, the literature indicates values lower than, or similar to, the Curauá fiber, for which Andrade et al., [33]found 4,04\% as mean value, and Tomazello Filho et al.,[54]obtained values between 6,02 \% and $7,98 \%$.

The ash content in the Curauá fiber was significantly lower than the mean values found in other vegetable fibers, like coconut and sisal fibers, for which Salazar and Leão [39] obtained 1,34 \% and 1,95\%ash contents, respectively. Trindade et al., [36] found 1,10\% of ash for the same fiber, value significantly high than this work.Usually, low ash contentis desired during the processing of materials, given that high amounts of these components affect negatively the wear of the cutting tools. Still, higher ash content implies in the increase of hardness, and when considered mineral panels, it is often suggested to use mineral additives such as silica or microssílica to improve the mechanical properties of the composite, increase its waterproofness and durability. The high variability of the properties of natural fibers occurs because they are dependent on various factors such as specie, place of origin, growing conditions, chemical composition, maturity, extraction and storage method (Table 4).

Table 4: Comparation of chemical, physical and mechanical properties of different fibers [12, 35, 41, 38, 40, 42, 43, 44, 45, 46, 47,48, 49].

\begin{tabular}{|c|c|c|c|c|c|c|}
\hline Fiber & $\begin{array}{c}\text { Cellulose } \\
(\%)\end{array}$ & $\begin{array}{c}\text { Lignin } \\
(\%)\end{array}$ & $\begin{array}{c}\text { Hemicellulose } \\
(\%)\end{array}$ & $\begin{array}{c}\text { Cristalynitty } \\
\text { Index }(\%)\end{array}$ & $\begin{array}{c}\text { Tensilestrength } \\
\text { (MPa) }\end{array}$ & $\begin{array}{c}\text { Young modulus } \\
\text { (GPa) }\end{array}$ \\
\hline Curauá & $70,7-73.6$ & $7,5-11,1$ & 9,9 & $50,2-67$ & 859-1404 & $20-36$ \\
\hline Jute & $61-71,5$ & 1215 & $13,6-20,4$ & 50 & $393-773$ & 26,5 \\
\hline Sisal & $67-78$ & $8 \quad 11$ & $10-14,2$ & $57-68$ & $551-635$ & $9,4-22$ \\
\hline Rami & 68,6 & 0,6 & 13,1 & 68 & 500 & 27,2 \\
\hline Coconut & $36-43$ & $36-43$ & $0,15-0,25$ & $40-44$ & $131-175$ & 413 \\
\hline E-glass & - & - & - & & $1800-3000$ & $72-83$ \\
\hline
\end{tabular}

\subsection{Crystallinity index}

The diffractogram of the Curauá fiber (Figure 1) is characteristic of lignocellulosic materials, where the amorphous halo and the crystalline peak are located between the angles $18^{\circ} \leq 2 \theta \leq 19^{\circ}$ and $22^{\circ} \leq 2 \theta \leq 23^{\circ}$. 


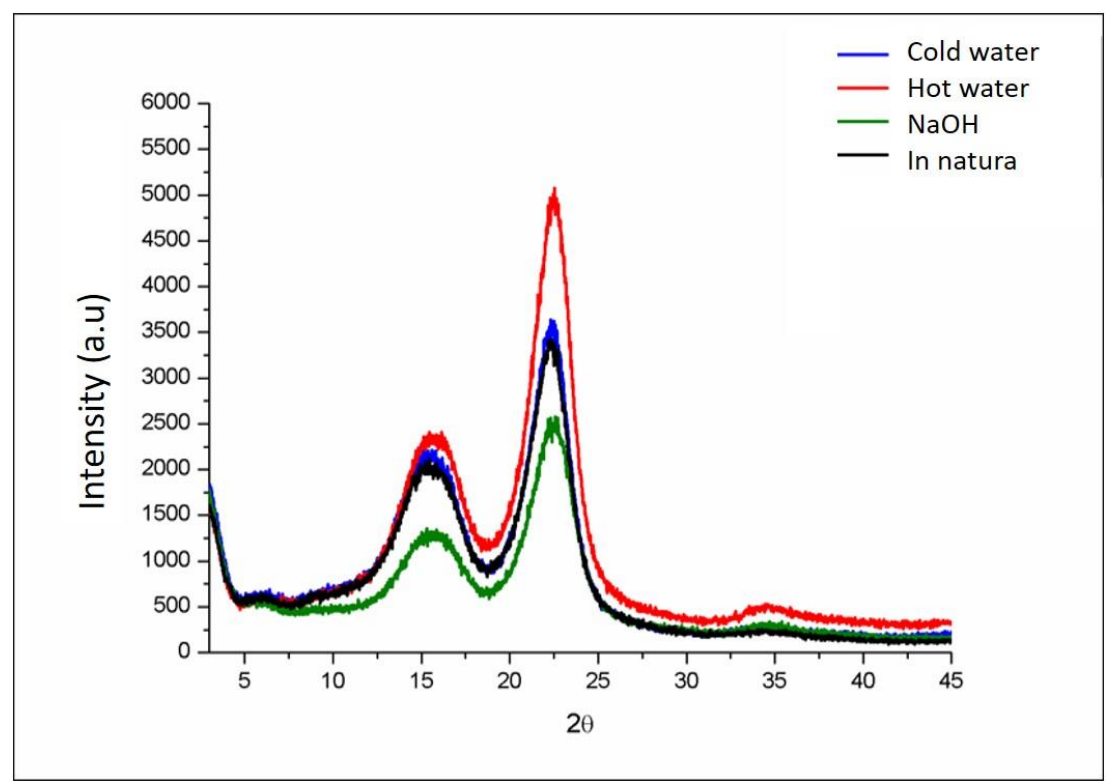

Figure 1: Diffractogram of the Curauá fiber in natura and after pre-theatments.

The crystallinity index of the untreated Curauá fibers was 73\%. The Curauá fiber had a crystallinity index similar to the sisal vegetable fiber (68\%), as reported by Oliveira et al., [54], and significantly higher than the coconut fibers, which was $40 \%$ on average, as reported by Ramírez et al., [55] and sugar cane bagasse fibers, with $47 \%$ of crystallinity finding by Trindade et al., (2004) [36]. However, it was lower than the indices of wood species such as eucalyptus, for which Lengowski et al., [56] obtained 79\% as mean value for Eucalyptus grandis.

Depending on the degree of crystallinity, lignocellulosic fibers may present different applications, such as reinforcement in polymer matrices, surface coating, ethanol production, emulsion thickener, nanocellulose production [56]. The flexibility of lignocellulosic fibers can be justified by this property; the higher crystallinity index increases the rigidity of the material. The crystallinity index in the Curauá fiber is an indicator of its potential to reinforce the cement-fiber panels, because the degree of crystallinity in the material is directly related to the mechanical properties[12, 35, 41, 45, 57] (Table 4).

The changes in the crystallinity indices were succinct after the pre-treatments performed on the Curauá fibers; the small change in crystalline index was based on the kind of treatment used on the fibers (Table 5). It can be seen that the treatment with hot water provided a 4,83\% increase of the crystallinity index. This treatment resulted in the highest increase of the crystallinity index, due to the removal of extractives (amorphous region), and the second treatment removed the largest amount of extractives from the fibers. On the other hand, the treatment with $1 \% \mathrm{NaOH}$ solution had the less numeric influence on the crystallinity index, with a $0,54 \%$ increase. This can be justified by the action of sodium hydroxide, which causes swelling of the Curauá fibers and, consequently, breaks the intra-crystalline bonds, thus diminishing the crystalline regions of the Curauá fibers.

Ferraz et al., [58] and Corradini et al., [59] observed that the treatments of cold water, hot water and $\mathrm{NaOH}$ reduced the extractive content and lignin for coconut fiber. Both authors found the greatest reduction with $\mathrm{NaOH}$ treatment, followed by hot water treatment. This reduction of the amorphous components of the fibers, increase the crystallinity index of these materials.

Generally, alkaline treatments reduce the regularity of cellulose molecules in lignocellulosic fibers by causing swelling of the fibers $[60,61,62]$. The degree of swelling and, consequently, the changes of crystalline structures depends on the type and concentration of alkaline substance used in treatment [63]. 
Table 5: Crystallinity index of treated fibers.

\begin{tabular}{l|l}
\hline Samples & Crystallinity index $(\%)$ \\
\hline Without treatment & 73,82 \\
\hline Cold water & 75,44 \\
\hline Hot water & 77,39 \\
\hline $\mathrm{NaOH}$ & 74,22 \\
\hline
\end{tabular}

\subsection{Inhibition index -Chemical compatibility between the Curauá fiber and Portland cements}

The mean values obtained by the inhibition assay are shown in Table 6 . The optimum material mixture is that which reaches the maximum temperature $(\mathrm{Tm})$ in the shortest time $(\mathrm{T})$, with maximum increase $(\mathrm{Sm})$.

Table 6: Inhibitory index of Curauá fibers mixed with Portland cement.

\begin{tabular}{l|l|l|l|l}
\hline Treatment & Time (h) & $\mathbf{T} \max \left({ }^{\mathbf{0}} \mathbf{C}\right)$ & $\mathbf{S} \max \left({ }^{\mathbf{0}} \mathbf{C} / \mathbf{h}\right)$ & $\mathbf{I}(\mathbf{\%})$ \\
\hline Without fiber & 12,09 & 42,1 & - & - \\
\hline Without treatment & 2,10 & 23,77 & 0,32 & $68,83 \mathrm{~d}(3,19)$ \\
\hline Cold water & 16,16 & 25,65 & 1,05 & $19,96 \mathrm{c}(2,57)$ \\
\hline Hot water & 17,00 & 27,22 & 4,67 & $7,88 \mathrm{~b}(2,53)$ \\
\hline $\mathrm{NaOH}$ & 16,04 & 33,12 & 3,15 & $1,21 \mathrm{a}(4,44)$ \\
\hline
\end{tabular}

a b c d - Different letters in column indicate statistical differences in the Tukey's test at $1 \%$ probability level. Values in parentheses are the percentage coefficient of variation of the samples

$\mathrm{I}=$ crystallinity index; $\mathrm{Tmax}=$ maximum temperature; Smax = maximum temperature increase in the curve.

The inhibition index (I) of the untreated Curauá-cement mixture was 68,83\%, considered "high inhibition" according to Okino [10], Ferraz et al., [58] and Olorunnisola [11] found an extreme inhibition for cement-fiber made by coconut fiber.

The inhibition indexes of treatments with cold and hot water were $19,96 \%$ and 7,88\% respectively, being graded as "moderate inhibition" according to Table 1 [10], but both have significant statistical difference between these treatments. The treatment with $\mathrm{NaOH}$ presented lower value of inhibition index, 1,21\% according to Table 1 [10], as "low inhibition" and have significant statistical difference between the others treatments. Thus, the efficiency of the chemical treatments on coir fibers at inhibition reduction of the Portland cement setting was evinced.

The treatment that had the lowest inhibition index was with $\mathrm{NaOH}$. This treatment was statistically different from the other treatments; it exhibited the best chemical compatibility when compared to the other treatments and the control. The treatments removed the extractives, waxes, polyphenols, carbohydrates, thus enhancing the chemical compatibility between the cement matrix and the Curauá fiber.

The inhibitory effect of this fiber was evident in relation to the reactions of cement hydration, once the standard mortar reached the peak temperature of $42,1^{\circ} \mathrm{C}$ in 12 hours, and the untreated fiber reached a maximum temperature of $23,77 \circ \mathrm{C}$ in about one hour, as presented in Figure 2. Assuredly, there is a great difference and it confirms that untreated coir fibers cause high inhibition on the cement setting. 
According to Zhou and Kamdem [64], the Tm reduction may be caused by a reduced value of cement hardening or by the presence of a determined mass of lignocellulosic material which did not contribute to generate heat but, on the contrary, absorbed it.

It could also be observed that cold water treatment decreased the inhibitory index, but the maximum temperature was relatively low $\left(25,65^{\circ} \mathrm{C}\right)$. The hot water treatment yielded slightly higher temperature $\left(27,22{ }^{\circ} \mathrm{C}\right)$ and inhibitory index was almost the same of that observed for hot-water treatment. The $\mathrm{NaOH}$ treatment treatment decreased the inhibitory index significantly, and the maximum temperature was relatively more close the cement without Curauá fiber $\left(33,1^{\circ} \mathrm{C}\right)$.

Miller and Moslemi [65], investigating the effect of standard substances present in lignocellulosic materials, found that cellulose, lignin, fatty acids and terpenes did not have a significant effect on compatibility reaction. However, hemicellulose and tannin significantly affected the characteristics of hydration. A pronounced inhibitory effect was produced by glucose, xylose, and quercetin. The effect of varying extractive levels on cement hydration is also significant, as described by Zhengentian and Moslemi [66]. The temperature decreases significantly when the percentage of extractives increases. This disruption of the hydration process totally affects the hardening of the cement and the development of the resistance. The compatibility of species for the production of cement-fiber panels, in general, decreases when extractive content increases, according to Hachmi and Moslemi [67].

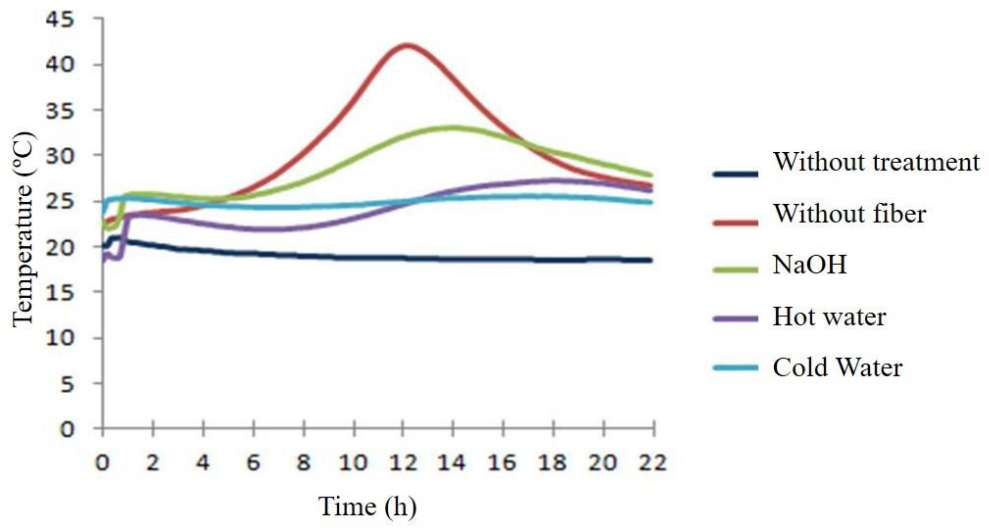

Figure 2: Curve of the hydration of the composites with in natura and treated fiber

Thedevelopmentofmechanicalstrengthof Portland cement pastes iscloselyrelatedtothevariablesthat determine thekineticsofthereactions [68]. In Figure 2 is possible to verify the temperature is of the portland cement paste during the picking and beginning of the hardening period (resistance gain), as well as the influence on the chemical reactions of the cement paste with the curaua fiber in the blend. A time delay was obtained (loss of plastic consistency) with addition of Curauá fiber, a fact that will influence the hardening of the composite.

\section{CONCLUSIONS}

Based on the results obtained in the present work, it can be concluded that:

- The in natura Curauá fiber had a high inhibition index, thus confirming the necessity for pre-treatment for make Curauá-cement panel.

- The treatments studied reduced the content of the amorphous regions,slightly modifying the crystallinity and minimizing the inhibition effect of Curauá fibers in the Portland cement matrix in the production of reinforced mineral panels.

- The treatments that indicated a high compatibility with cement were the ones with hot water and $\mathrm{NaOH}$. 


\section{ACKNOWLEDGMENT}

The authors thank the laboratories of X-Rays Optics and Instrumentation and Wood Chemistry of Federal University of Paraná.

\section{BIBLIOGRAPHY}

[1] VAN ELTEN, I. G. J., "Production of wood wool cement board and wood strand cement board (eltoboard) on one plant and applications of the products", In: 11th International Inorganic-Bonded Fiber Composites Conference, pp. 1-11, Brasil, 2006.

[2] BERALDO, A. L., CARVALHO, J. V., "Compósitos Eucalyptus grandis-cimento Portland”, Scientia Florestalis, n. 65, pp. 150-161, 2004.

[3] MATOSKI, A., IWAKIRI, S., “Avaliação das propriedades físico-mecânicas de painéis de cimento-madeira utilizando farinha de madeira com granulometria controlada", Árvore, v. 37. n.2. pp. 149-158, 2007.

[4] CAMPELLO, E. F., DARWISH, F. A., PEREIRA, M. V.C, “Comportamento em fadiga de compostos cimentícios reforçados por polpa de bambu", In: $8^{\circ}$ Congresso Iberoamericano de Engenharia Mecânica, pp. 9, Cusco, Peru, 2007.

[5] FERREIRA, J.F., SBRUZZI, D., BARROS, K.V.G., et al., "Extração e Caracterização de uma Enzima Proteolítica do Curauá (Ananaserectifolius)", Exacta, v.8, n.2, pp. 179- 184, 2010.

[6] PICANÇO, M.S., GHAVAMI, K., "Comportamento à compressão de argamassas reforçadas com fibras vegetais da Amazônia", REM: Revista Escola de Minas, v.61, n.1, pp. 13-18, 2008.

[7] SPINACÉ, M.A.S., JANEIRO, L.G., BERNADINO, F.C., et al., "Poliolefinas reforçadas com fibras vegetais curtas: sisal x Curauá", Polímeros, v. 21, n 3, 2011.

[8] WEATHERWAX, R. C., TARKOW, H., "Effect of wood on setting of Portland cement," Forest, v.14, pp. 567-570, 1984.

[9] GEETHAMMA, V.G.K., MATHEW, T., LAKSHMINARAYNAN, R., et al.,"Composite of short coir fibres and natural rubber: effect of chemical modification, loading and orientation of fibre", Polymer, v. 39, n. 6-7, pp. 483-1491,1998.

[10] OKINO, E.Y.A., SOUZA, M.R.S., SANTANA, M.A.E., et al., "Chapa aglomerada de cimento-madeira de Hevea brasiliensis Müll”, Árvore, v. 28, n. 3, p. 451-457, 2004.

[11] OLORUNNISOLA, A. O. "Effects of pre-treatment of rattan (Laccospermas ecundiflorum)on the hydration of Portland cement and the development of a new compatibility índex", Cement and Concrete Composites, v. 30, pp. 37-43, 2008.

[12] BLEDZKI, A.K., GASSAN, J., "Composites Reinforced with Cellulose Based Fibres", Progress in Polymer Science, v. 24, n. 2, pp. 221-274, 1999.

[13] SPARNIAS, E. Mechanical properties of flax fibers and their composites, P.hD Thesis, Luleå University of Technology, Sweden, 2006.

[14] MOSLEMI, A. A., LIM, Y. T., "Compatibility of southern hardwoods with Portland cement", Forest Products Journal, v. 34, n. 7/8, pp. 22-26, 1984.

[15] ALBERTO, M.M., MOUGEL, E., ZOULALIAN, A., "Compatibily of some tropical harwoods species with Portland cement using isothermal calorimetry", Forest Products Journal, v.50, n. 9, p. 83-88, 2000.

[16] LEE, A.W.C., SHORT, P. H., "Pretreating hardwood for cement-bonded excelsior board", Forest Products Journal, v. 39, n.10, p.68-70, 1989.

[17] FRYBORT, S., MAURITZ, R., TEISCHINGER, A., et al., "Cement bonded composites - a mechanical review", BioResources, v. 3, n. 2, pp.602-626, 2008.

[18] ALBINANTE, S.R., PACHECO, E. B.A.V., VISCONTE, L.L.Y., "Revisão dos tratamentos químicos da fibra natural para mistura com poliolefinas", Química Nova, v. 36, n.1, pp.114-122, 2013. 
[19] HU, X. P., HSIEH, Y. L., "Effects of dehydration on the crystalline structure and strength of developing cotton fibers", Textile Research Journal, v. 71, n. 3, p. 231 - 239, Princeton, 2001.

[20] BERALDO, A. L., PIMENTEL, L.L., LIMA, I. L., et al., "Efeito de Tratamentos Físicos - Químicos sobre a Resistência à Compressão de Compósitos Madeira-Cimento", IN: Encontro Brasileiro em Madeiras e em Estruturas de Madeira 6º $^{\circ}$ artigo técnico, Florianópolis, v.4, pp.261-271, 1998.

[21] DIQUÉLOU, Y., GOURLAY, E., ARNAUD, L., et al., "Impact of hemp shiv on cement setting and hardening: Influence of the extracted components from the aggregates and study of the interfaces with the inorganic matrix", Cementand Concrete Composites, v. 55, pp. 112-121, 2015.

[22] HOFSTRAND, A.D., MOSLEMI, A.A., GARCIA, J.F., "Curing characteristics of wood particles from nine northern Rocky Mountain species mixed with portland cement", Forest, v. 34, n.2, pp. 57 - 61, 1984.

[23] MORI, F. A., LOPES, Y. L. V., MENDES, L. M., et al., "Estudo da compatibilidade entre a madeira e as cascas de Eucalyptusgrandise cimento portland ", Ciência Florestal, Santa Maria, v.17, n. 3, pp. 257-264, 2007.

[24] GNANAHARAN, R., DHAMODARAN, T.K., "Suitability of some tropical hardwoods for cement-bonded wood-wool board manufacture", Holzforschung, Berlin, v. 39, n. 6, p. 337- 340, 1985.

[25] MOSLEMI, A.A., GARCIA, F.J., HOFSTRAND, A.D., "Effect of various treatments and additives on wood-Portland cementwater systems", Wood and Fiber Science, v. 15, n. 2, pp. 164-176. 1983.

[26] MATOSKI, A., Utilização de pó de madeira com granulometria controlada na produção de painéis de cimento-madeira, Tese de D.Sc, Universidade Federal do Paraná, Curitiba, Brasil, 2005.

[27] PEREIRA, C.L., SAVASTANO, H.JR., PAYÁ, J., et al.,"Use of highly reactive Rice husk ash in the production of cement matrix reinforced with green coconut fiber", Industrial Crops and Products, v. 42, pp. 8896, 2013.

[28] TAPPI. Technical Association of the Pulp and Paper Industry. Acid-insolublelignin in woodandpulp. T 222 - Determinação do teor de lignina da madeira, 2006.

[29] TAPPI .Technical Association of the Pulp and Paper Industry. T 413 - Determinação do teor de cinzas da madeira, 2008.

[30] NBR. Associação Brasileira de Normas Técnicas. Normas Técnicas. NBR 7988 - Determinação de extratíveis da madeira em água, 2012.

[31] NBR. Associação Brasileira de Normas Técnicas. Normas Técnicas. NBR 7990 - Madeira - Determinação do material solúvel em hidróxido de sódio a 1\%, 2010.

[32] NBR. Associação Brasileira de Normas Técnicas. Normas Técnicas. NBR 7987 - Determinação de extrativos totais da madeira, 2012.

[33] ANDRADE, M. C. N., MINHONI, M. T. A., SANSÍGOLO, et al., "Análise química da madeira e casca de diferentes tipos de eucalipto antes e durante o cultivo de shiitake em toras", Árvore, v. 34, n. 1, pp.165-175, 2010.

[34] SEGAL, L., CREELY, J.J., MARTIN, A.E., et al.,"An empirical method for estimating the degree of crystallinity of native cellulose using the $\mathrm{x}$ - ray diffractometer”,Textile Research Journal, v. 29, n. 10, pp. 786 794, Princeton, 1959.

[35] MOHANTY, A.K., MISRA, M., HINRICHSEN, G., "Biofibres Biodegradable Polymers and Biocomposites: An Overview", Macromolecular Materials and Engineering, v. 276/277, n. 1, pp.1-24, 2000.

[36] TRINDADE, W.G., HOAREAU, W., RAZERA, I.A.T., et al., "Phenolic thermoset matrix reinforced with sugar cane bagasse fibers: attempt to develop a new fiber surface chemical modification involving formation of quinones followed by reaction with furfuryl alcohol”, Macromolecular Materials and Engineering., v. 289, n. 8, pp. 728, 2004.

[37] CASTRO, D.O., RUVOLO-FILHO A., FROLLINI, E., "Materials prepared from biopolyethylene and Curauá fibers: Composites from biomass", Polymer Testing, v. 31, n. 7, pp.880-888, October 2012.

[38] SILVA, R.V., AQUINO, E.M.F., “Curauá Fiber: A New Alternative to Polymeric Composites”, Journal of Reinforced Plastics and Composites, v. 27, n. 1, 2008.

[39] SALAZAR, V.L. P., LEÃO, A.L., "Biodegradação das fibras de coco e de sisal aplicadas na indústria automotiva”, Energia e Agricultura, v. 21, n. 2, pp. 99-133, 2006. 
[40] SILVA, R.V.I., AQUINO, E.M.F., RODRIGUES, L.P.S., et al., "Desenvolvimento de um compósito laminado híbrido com fibras natural e sintética”, Revista Matéria, v. 13, n. 1, pp. 154 - 161, 2008.

[41] GOWDA, T. M., NAIDU, A.C.B., CHHAYA, R. "Some Mechanical Properties of Untreated Jute Fabricreinforced Polyester Composites”, Composites, v. 30, n. 3, pp. 277-284, 1999.

[42] LEÃO, A.L., CARASCHI, J.C., TAN, I.H., KOZLOSWKI, R., MANYS, S., "Fibra de Curauá: uma alternativa na produção de termoplásticos reforçados”, Plástico Industrial, v. 3, n. 31, pp.214-229, 2001.

[43] YOUNG, R.A. "Fibers (Vegetable)".Kirk-Otthmer encyclopedia of chemical Tecnology 4th.Ed., v.10. J. Wiley\& Sons, Inc. pp.727-744, 1994.

[44] RAZERA, I.A.T., FROLLINI, E., "Use of coir as a reinforcing material of phenolic and lignophenolic matrix composites fiber characterization and composite properties." In: Fifth international symposium on natural polymers and composites, In: 8th Brazilian Symposium on the Chemistry of Lignins and Others Wood Components (ISNaPol 2002) proceedings, São Pedro, Brasil, 1-4 September, p. 253-6, 2002.

[45] TOMCZAK, F., SATYANARAYANA, K.G., SYDENSTRICKER, T. H. D., "Studies on Lignocellulosic Fibers of Brazil: Part III- Morphology and Properties of Brazilian Curauá Fibers", Composites. Part A, Applied Science and Manufacturing, v. 38, pp. 2227-2236, 2007.

[46] TOMCZAK, F., SYDENSTRICKER, T.H.D., SATYANARAYANA, K.G., "Studies on Lignocellulosic Fibers of Brazil: Part II- Structure and Properties of Brazilian Coconut Fibers", Composites. Part A, Applied Science and Manufacturing, v. 38, pp. 1710-1721, 2007.

[47] WAllENBERGER, F.T., WESTON, N. Natural Fibers, Plastics and Composites, Springer Science \& Business Media, 28 de jun de 2011, - pp. 370.

[48] REVISTA AGROAMAZÔNIA, In: www.revistaagroamazonia.com.br 13a edition, 2004.

[49] TOMAZ, R.M.A.G., BITTENCOURT, E., SABINO, N.P., et al., "Determinação dos índices de cristalinidade de fibras celulósicas”, Bragantia, v.53, n.1, pp.121-126, 1994.

[50] GATTO, D. A., HASELEIN, C. R., SANTINI, E. J., et al., "Características tecnológicas das madeiras de Lueheadivaricata, Caryaillinoinensis E Platanus x acerifolia quando submetidas ao vergamento", Ciência Florestal, v. 18, n. 1, pp. 121-131, Santa Maria, 2008.

[51] TROEDEC, M.L., SEDAN, D., PEYRATOUT, C., et al., "Influence of various chemical treatments on the composition and structure of hemp fibres", Composites: Part A. v.39, pp. 514-522, 2008.

[52] FERRAZ, J. M., MENEZZI, C. H. S., TEIXEIRA, D. E., et al., "Effects of treatment of treatment coir fiber and cement/fiber ratio on properties of cement-bonded composites”, Bioresources, v. 6, pp. 3481-3492, 2011.

[53] TOMAZELLO FILHO, M., LATORRACA, J. V .F., FISHER, F. M., et al., "Evaluation of Pinustaeda L. Seed Dispersal by Tree-ring Analysis of Natural Regenerated Trees”, Floram, v. 24, 2017.

[54] OLIVEIRA, F. B., TEIXEIRA, E. M., TEODORO, K. B. R., et al., "Obtenção de nanofibras de celulose a partir de fibras de sisal para atuar como reforço em matrizes biodegradáveis”, In:Congresso Brasileiro de Polímeros, 2009.

[55] RAMÍREZ, M.G.L., KESTUR, S.G., GONZÁLEZ, R.M., et al.,’Bio-compositesof cassava starchgreencoconutfiber", CarbohydratePolymers, v. 102, pp. 575-583, 2014.

[56] LENGOWSKI, E. C., MUNIZ, G. I. B., NISGOSKI, S., et al., “Avaliação de métodos de obtenção de celulose com diferentes graus de cristalinidade”, ScientiaForestalis, v. 41, n. 98, pp. 185-194, jun, 2013.

[57] MARTIN, A.R., MARTINS, M.A., MATTOSO, L.H.C., et al., "Caracterização química e estrutural de fibra de sisal da variedade agave sisalana”, Polímeros: ciência e tecnologia, v. 19, n. 1, pp. 40-46, 2009.

[58] FERRAZ, J.M., DELMENEZZI, C.H.S., SOUZA, M.R., et al., "Compatibility of Pretreated Coir Fibres (Cocos nucifera L.) with Portland Cement to Produce Mineral Composites", InternationalJournalofPolymer Science, 2012.

[59] CORRADINI, E., ROSA, M.F., MACEDO, B.P., et al., "Composição quírmica, propriedades mecânicas e térmicas da fibra de frutos de cultivares de coco verde", Revista Brasileira de Fruticultura, v. 31, n. 3, pp. 837846, 2009. 
[60] ICHAZO, M. N., ALBANO, C., GONÇALVEZ, J., et al., "Polypropylene/woodflourcomposites: treatmentsandproperties", CompositeStructural. v. 54, pp. 207, 2001.

[61] JOSEPH, K., THOMAS, S., PAVITHRAN, C., "Effect of chemical treatment on the tensile properties of short sisal fibre-reinforced polyethylene composites", Polymer, v. 37, n. 23, pp. 5139-5149, 1996.

[62] TABIL, L.G., LI, X., PANIGRAHI, S. J., "Chemical Treatments of Natural Fiber for Use in Natural. FiberReinforced Composites: A Review", Polymer Environ, v. 15, pp. 25-33, 2007.

[63] WEYENBERG, I.V., TROUNG, T.C., VANGRINDE, B., et al., "Improving the Properties of UD Flax Fibre Reinforced Composites by Applying an Alkaline Fibre Treatment", Composites Part A: Applied Science and Manufacturing, v. 37, pp. 1368-1376, 2006.

[64] ZHOU, Y., KAMDEM, D. P. "Effect of cement/wood ratio on the properties of cement-bonded particleboard using CCA treated wood removed from service", Forest Products Journal, v. 52, n. 3, pp. 77-81, 2002.

[65] MILLER, D.P., MOSLEMI, A.A., "Wood-Cement Composites: Effect of Model Compouds on Hydratation Characteristics and Tensile Strenghth", Wood and Fiber Science, v. 23, n.4, pp. 4724-82, 1991.

[66] ZHENGTIAN, L., MOSLEMI, A. A., "Effect of Western Larch Extractives on cement setting”, Forest Products Journal, v. 36, n. 1, pp. 53-54, 1986.

[67] HACHMI, M., MOSLEMI, A.A., "Correlation between wood-cement compatibility wood extractives", Forest Products Journal, v. 39, n. 6, pp. 55-58, 1989.

[68] OLIVEIRA, C., GARCIA, J.R., PANDOLFELLI, V.C., "Cinética de hidratação de ligantes à base de alumina hidratável ou aluminato de cálcio", Cerâmica, v.53, n.325, pp. 20-28, 2007. 